\title{
Haematological studies on vegans
}

\author{
BY T. A. B. SANDERS AND F. R. ELLIS \\ Department of Pathology, Kingston Hospital, \\ Kingston-upon-Thames, Surrey, KT2 $7 B D$ \\ AND J. W. T. DICKERSON \\ Department of Biochemistry, Nutrition Division, \\ University of Surrey, Guildford, Surrey, $\mathrm{GU}_{2}{ }_{5} \mathrm{XH}$
}

(Received I9 May 1977 - Accepted 29 November 1977)

I. The concentrations of vitamin $\mathbf{B}_{12}$ and folate in the serum and folate in the erythrocytes were determined and full blood counts made on a series of caucasian vegans and omnivore controls.

2. The blood counts and films were normal in all the vegans and no subject had a haemoglobin concentration below the lower limit of normality.

3. Although within the normal range, male but not female vegans had lower values for erythrocyte counts and higher values for mean corpuscular volume and mean corpuscular haemoglobin than their controls regardless of whether they were taking vitamin $B_{12}$ supplements or not.

4. The mean serum vitamin $B_{12}$ concentration was lower in the vegans not taking vitamin $B_{12}$ supplements and in those using foods supplemented with the vitamin than in the controls, but in no subject was it below $80 \mathrm{ng} / \mathrm{l}$.

5. The serum folate concentrations were higher in the vegans than in their controls. The mean value for erythrocyte folate tended to be greater in the vegans not taking vitamin $\mathbf{B}_{12}$ supplements. No subject had an erythrocyte folate concentration of less than $100 \mu \mathrm{g} / \mathrm{l}$.

6. It is concluded that megaloblastic anaemia is very rare in caucasian vegans and that a diet consisting entirely of plant foods is generally adequate to promote normal blood formation providing it is composed of a mixture of unrefined cereals, pulses, nuts, fruit and vegetables and is supplemented with vitamin $\mathbf{B}_{12}$.

Vegans are a minority group who for ethical reasons eat no foods of animal origin. Vitamin $B_{12}$ is a product of microbial synthesis and is not found in plant foods (Lester Smith, 1965) and therefore should be absent from vegan diets. Rose (1976) claims that megaloblastic anaemia is a predictable consequence of vegan dietary habits adopted in Britain. Neurological symptoms (Badenoch, I952; Wokes, Badenoch \& Sinclair, 1955; Smith, I962) and megaloblastic anaemia (Hines, I966) apparently due to a dietary deficiency of vitamin $B_{12}$ have been reported in caucasian vegans. Megaloblastic anaemia, attributed to a dietary deficiency of vitamin $\mathrm{B}_{12}$, in vegetarian Asian immigrants to this country has been reported (Stewart, Roberts \& Hoff brand, I970; Britt, Harper \& Spray, I97I ; Roberts, James, Petrie, Morgan \& Hoffbrand, 1973). On the other hand, Hardinge \& Stare (I954a), West \& Ellis (1966) and Ellis \& Montegriffo (1970) failed to find any clinical or haematological evidence of vitamin $\mathbf{B}_{\mathbf{1 2}}$ deficiency in their studies of caucasian vegans, although the serum vitamin $B_{12}$ concentrations of some of their subjects indicated deficiency. In view of the trend towards vegetarianism in this country, and because many people in the developing countries, especially those of Asia, eat a mainly vegetarian diet, it is important to establish whether a vegan diet can promote normal blood formation.

\section{SUBJECTS, MATERIALS AND METHODS}

Vegan subjects were contacted through the Vegan Society; these were all caucasians and were mainly from the professional and middle classes. A total of thirty-four vegans were examined (twenty male and fourteen female). The average age of the vegan subjects was 


\begin{tabular}{|c|c|c|c|c|c|c|c|}
\hline Sex & $\underset{\text { (years) }}{\text { Age }}$ & $\begin{array}{c}\text { Previous } \\
\text { period on } \\
\text { vegetarian } \\
\text { diet } \\
\text { (years) }\end{array}$ & $\begin{array}{l}\text { Period } \\
\text { on } \\
\text { vegan } \\
\text { diet } \\
\text { (years) }\end{array}$ & $\begin{array}{c}\text { Type of } \\
\text { vitamin } B_{12} \\
\text { supplement } \\
\text { taken }\end{array}$ & $\begin{array}{c}\text { Vitamin } \\
\mathbf{B}_{12} \\
\text { con- } \\
\text { centration } \\
\text { (ng/l) }\end{array}$ & $\begin{array}{c}\text { Erythrocyte } \\
\text { count } \\
\left(1 \times 10^{12} \text { cells } / 1\right)\end{array}$ & $\begin{array}{c}\text { Haemo- } \\
\text { globin } \\
\text { concentra } \\
\text { tion } \\
(\mathrm{g} / \mathrm{dl})\end{array}$ \\
\hline Male & 5 & - & 5 & Food & 375 & $4 \cdot 38$ & $13 \cdot 2$ \\
\hline Male & 5 & - & 5 & Food & - & 4.49 & 13.6 \\
\hline Male & 10 & - & 3 & None & 130 & $4 \cdot 32$ & $13 \cdot 0$ \\
\hline Male & 21 & 5 & 2 & None & 200 & 4.45 & $14 \cdot 3$ \\
\hline Male & 22 & 3.5 & 4 & Food & 160 & 5.05 & $16 \cdot I$ \\
\hline Male & 22 & 2 & 2 & Food & 210 & $5 \cdot 53$ & 15.6 \\
\hline Male & 25 & 3 & I & Food & 245 & 4.26 & $13 \cdot I$ \\
\hline Male & 25 & - & 3 & Food & 240 & 4.46 & 14.0 \\
\hline Male & 28 & - & 28 & Food & 322 & 3.91 & 14.0 \\
\hline Male & 30 & 3 & 2 & Tablet & 675 & 3.90 & $13 \cdot 3$ \\
\hline Male & $3 \mathrm{I}$ & 2 & 8 & Tablet & 500 & $4 \cdot 47$ & 14.4 \\
\hline Male & $3 \mathrm{I}$ & I & 6 & None & 230 & $4 \cdot 72$ & $14 . I$ \\
\hline Male & 35 & 3 & 0.5 & None & 94 & 3.96 & 14.3 \\
\hline Male & 46 & - & 10 & Food & 185 & $4 \cdot 65$ & 15.2 \\
\hline Male & 46 & 30 & 5 & Tablet & 375 & 4.94 & 16.0 \\
\hline Male & 48 & 3 & 5 & Food & 150 & 443 & 13.4 \\
\hline Male & 49 & I & 13 & None & 120 & $4.8 I$ & 1399 \\
\hline Male & 57 & - & 17 & Tablet & 215 & $4 \cdot 77$ & $16 \cdot I$ \\
\hline Male & 64 & 20 & 30 & Food & 250 & $4 \cdot 49$ & I5.1 \\
\hline Male & 84 & - & 3 & None & 100 & $4 \cdot 19$ & 14.3 \\
\hline Female & 3 & - & 3 & Food & - & $4 \cdot 27$ & $12 \cdot 2$ \\
\hline Female & 7 & - & 7 & Food & 155 & 4.47 & 12.6 \\
\hline Female & 12 & - & 3 & None & 220 & $4 \cdot 25$ & $13 \cdot 2$ \\
\hline Female & 22 & 4 & 3 & Food & 375 & 4.35 & $13 \cdot 2$ \\
\hline Female & 28 & 3 & 3 & Food & 325 & $4 \cdot 20$ & $13 \cdot 9$ \\
\hline Female & 29 & 2 & 8 & Tablet & 500 & $4 \cdot 39$ & 13.6 \\
\hline Female & 33 & 6 & 6 & None & 180 & $4 \cdot 73$ & 14.8 \\
\hline Female & 39 & - & 3 & None & 130 & $4 \cdot 64$ & 14.8 \\
\hline Female & 39 & 12 & 12 & Food & 220 & 4.59 & 12.9 \\
\hline Female & 39 & 5 & 3 & Food & 280 & 4.07 & 13.5 \\
\hline Female & 43 & 17 & 26 & Tablet & 260 & $4 \cdot 4 \mathrm{I}$ & 13.6 \\
\hline Female & 50 & 4 & I & Food & 225 & $4 \cdot 58$ & $14 \cdot 4$ \\
\hline Female & 58 & 0.5 & 4 & None & 235 & $4 \cdot 30$ & $13 \cdot 7$ \\
\hline Female & 66 & - & 17 & Food & 330 & $4 \cdot 31$ & I 2.5 \\
\hline
\end{tabular}

thirty-four (range 3-84 years). The length of time the vegans had been on the diet was noted and dietary information was collected from all subjects by questionnaire; in the case of young children the information was provided by their parents. In addition 7 -d weighed dietary survey information on four vegan subjects was available. Omnivore control subjects were healthy hospital staff, their relatives and friends. Blood samples were drawn by venepuncture with stasis between 9.00 hours and 12.00 hours from subjects after an overnight fast. Portions anticoagulated with EDTA were taken for full blood counts and measurement of haemoglobin concentration on a Coulter Model S cell counter (Coulter Instruments, Luton, Beds.) and stained blood films were examined. Serum vitamin $B_{12}$ concentrations (Spray, 1955) and serum and erythrocyte folate concentrations (Chanarin, 1969) were assayed microbiologically. The Fisher-Behrens test was used for testing differences between mean values (Campbell, 1967).

\section{RESULTS}

All the vegan and omnivore subjects seemed healthy when studied. The vegan subjects had been on the diet for an average of 7 years (range, 6 months-30 years; see Table I). 


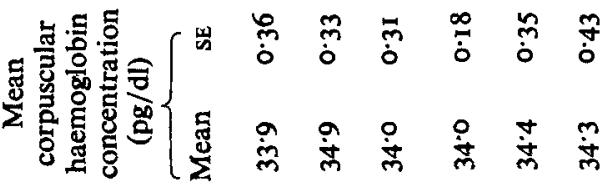

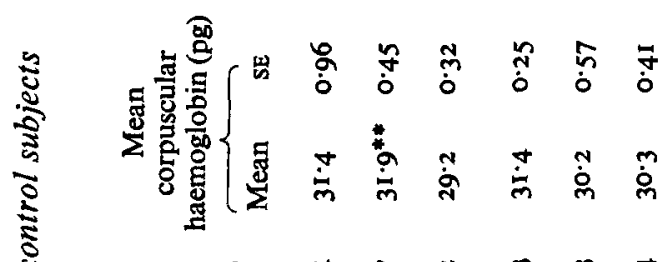

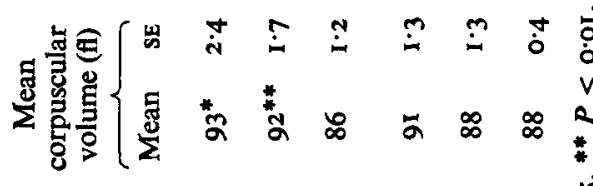

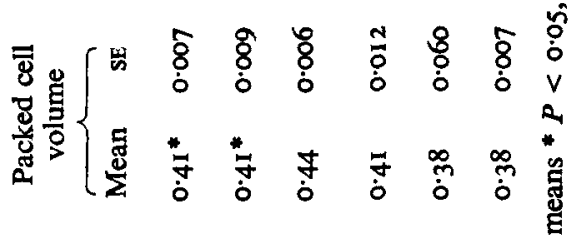

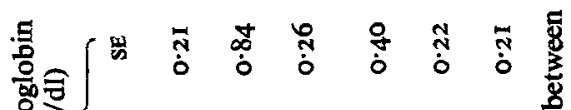

丵

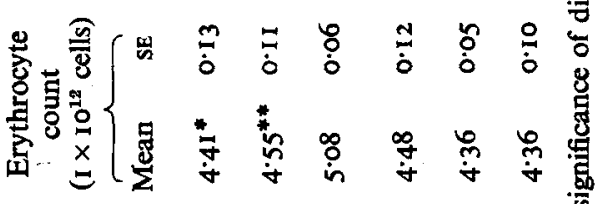

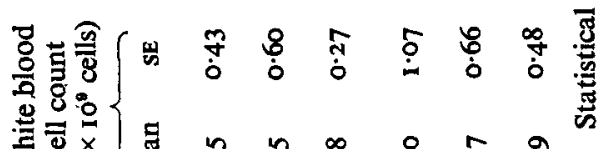

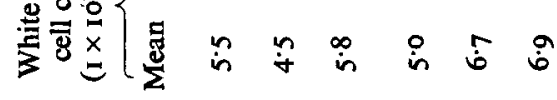

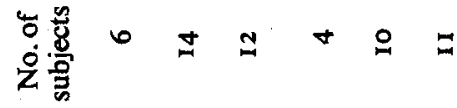

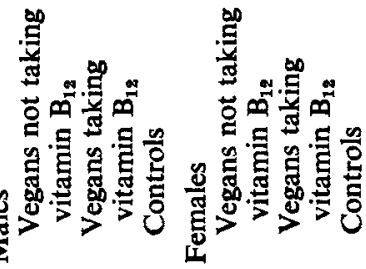


Table 3. Concentrations of serum vitamin $B_{12}$ and serum and erythrocyte folate in vegans and omnivore control subjects

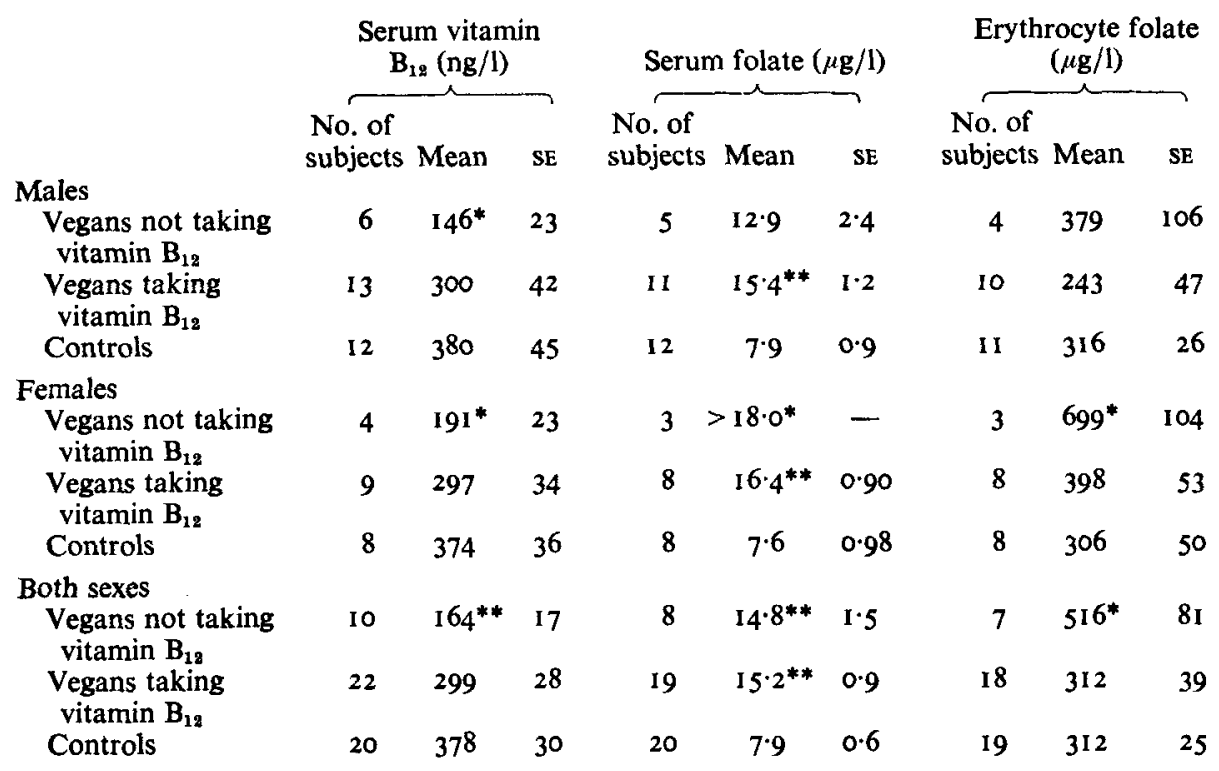

Statistical significance of difference between means $* P<0.05,{ }^{* *} P<0.0$.

Six subjects had been born of and breast-fed by vegan mothers and weaned and reared on a vegan diet. None of the vegan subjects admitted eating meat, fish, eggs, milk products, or any other foods of animal origin. The results of the 7-d weighed dietary intake survey on four of the vegan subjects suggested an average daily iron intake of $23 \mathrm{mg} / \mathrm{d}$ (range I 5-3I mg/d); protein on average accounted for $12 \%$ of the dietary energy (range $\mathrm{II}-13 \%$ ). Vegan subjects were divided into two groups depending whether they took vitamin $B_{12}$ supplements or not. Six vegan subjects were taking vitamin $B_{12}$ tablets (Cytacon; Glaxo Laboratories Ltd, Greenford, Middlesex) on a regular basis, eighteen subjects were using foods supplemented with the vitamin (Barmene, Velactin, Plamil, Granogen) and ten subjects were taking neither tablets nor foods supplemented with the vitamin. The mean serum vitamin $B_{12}$ concentration was higher in those vegans taking vitamin $B_{12}$ lablets than those using foods supplemented with the vitamin $(421 \pm 70 \mathrm{ng} / \mathrm{l}$ (mean $\pm \mathrm{SE}$ ) compared with $253 \pm 19 ; P<0.05$ ). Four of the ten subjects who were not taking vitamin $B_{12}$ supplements had normal serum levels of the vitamin (greater than $180 \mathrm{ng} / \mathrm{l}$ ): their vitamin $\mathrm{B}_{12}$ values were $200,230,220$ and $235 \mathrm{ng} / \mathrm{l}$, and they had been on the diet for $2,6,3$, and 4 years respectively.

Tables 2 and 3 summarize the results in thirty-four vegans and twenty-three omnivore subjects. No subject had a haemoglobin value below the lower limit of normality ( $13.0 \mathrm{~g} / \mathrm{dl}$ for males, WHO I968; II.5 g/dl for females, Chanarin 1969). No subject had a serum vitamin $B_{12}$ concentration indicative of deficiency (less than $80 \mathrm{ng} / \mathrm{l}$, WHO 1968) or a serum folate value less than $2.5 \mu \mathrm{g} / \mathrm{l}$. There was no evidence of macrocytosis or microcytosis, no polysegmented neutrophils were seen and all the blood films were normochronic when examined.

Although the blood films were normal, a number of statistically significant differences were noted between the vegans and their omnivore controls: in the male but not the female vegans the mean values for erythrocyte count and packed cell volume were lower $(P<0.01$ 
and $P<0.05)$ and the mean values for mean corpuscular haemoglobin and mean corpuscular volume were higher (both $P<0.01$ ) regardless whether they were taking vitamin $\mathrm{B}_{12}$ supplements or not; the mean values for serum vitamin $\mathrm{B}_{12}$ concentration was lower in the vegans not taking vitamin $\mathrm{B}_{12}$ supplements $(P<0.0 \mathrm{I})$ and in those using foods supplemented with the vitamin $(P<0.01)$ but not in those taking vitamin $\mathrm{B}_{12}$ tablets; the mean value for serum folate was much higher in the vegans $(P<0.01)$; the mean erythrocyte folate concentration tended to be higher $(P<0.05)$ in the vegans not taking vitamin $B_{12}$ supplements.

\section{DISCUSSION}

The blood counts and films of the vegan subjects were essentially normal, in agreement with Hardinge \& Stare (I954a), West \& Ellis (I966) and Ellis \& Montegriffo (1970). The findings that male but not female vegans tended to have lower values for erythrocyte counts and higher values for mean corpuscular volume and mean corpuscular haemoglobin are novel. Cotes, Dabbs, Hall, McDonald, Miller, Mumford \& Saunders (I970) found no difference between the physiological response to exercise of female caucasian vegans and omnivores; no similar studies of male caucasian vegans appear to have been made and would be of interest.

The finding of lower serum vitamin $B_{12}$ and higher serum folate values in vegans is in agreement with previous reports (West \& Ellis, 1966; Ellis \& Montegriffo, 1970). Erythrocyte folate concentrations in vegans do not appear to have been previously reported. The level of serum folate is often increased in patients with untreated pernicious anaemia, while the erythrocyte folate concentration is abnormally low (Chanarin, 1969) apparently because vitamin $B_{12}$ is necessary for the uptake of folate into the erythrocyte (Nutrition Reviews, 1975). In this study none of the vegan subjects had an abnormally low erythrocyte folate concentration; this would suggest, firstly, that none of the subjects were suffering from vitamin $B_{12}$ deficiency and, secondly, that the high serum folate concentrations found in many of the vegan subjects were due to high dietary intakes of folate. This might explain why megaloblastic anaemia was not encountered in our vegan subjects.

Vegans tend to have lower intakes of energy, protein, fat, calcium, riboflavin, saturated fatty acids and vitamin $B_{12}$, and higher intakes of unrefined carbohydrates, thiamin, vitamin $\mathrm{C}$, vitamin A, polyunsaturated fatty acids, fibre, folate and iron than omnivores (Hardinge \& Stare, I954a; Hardinge, Crooks \& Stare, 1962; Miller \& Mumford, I972; Mumford \& Ellis, unpublished results).

Vitamin $B_{12}$ is the vitamin most likely to be deficient in vegan and occasionally vegetarian diets. The present study has provided no evidence of pathologically low values of vitamin $B_{12}$ in the serum of vegans. In twenty-four of the subjects this could be attributed to them taking vitamin supplements or foods supplemented with the vitamin. There were, however ten subjects who did not take supplements and it was therefore surprising that these subjects did not show evidence of vitamin $B_{12}$ deficiency. Some vegans may obtain the vitamin through the accidental ingestion of insects or from micro-organisms, that produce the vitamin in their food or as a result of poor personal hygiene. Alternatively, some vegans may be able to absorb vitamin $B_{12}$ which has been synthesized by their own gut microflora.

A few cases of vitamin $B_{12}$ deficiency, sometimes resulting in neurological symptoms, have been reported in caucasian vegans apparently due to dietary deficiency (Badenoch, 1952; Wokes et al. 1955; Smith, 1962; Hines, 1966; Verjaal \& Timmermans-van den Bos, 1967; Winawer, Strieff \& Zamcheck, 1967; Ledbetter \& del Pozo, 1969; Misra \& Fallowfield, 197I). The results provided by Badenoch (1952), Wokes et al. (1955) and Smith (I962) are incomplete and their diagnoses of subacute combined degeneration of the spinal cord due to vitamin $B_{12}$ deficiency are not convincing (Pallis \& Lewis, 1974). However, this 
and other studies (Hardinge \& Stare, 1954a; West \& Ellis, 1966; Ellis \& Montegriffo 1970; Armstrong, Davies, Nicol, van Merwyk \& Larword, 1974) failed to find symptoms attributable to a dietary deficiency of vitamin $B_{12}$. This would suggest that dietary vitamin $B_{12}$ deficiency is rare among vegans. However, as there is a possibility of developing symptoms of vitamin $B_{12}$ deficiency, vegans should supplement their diets with the vitamin. The maximum amount that can be absorbed is in the region of $3 \mu \mathrm{g}$ at any one meal (Heyssel, Bozian, Darby \& Bell, 1966), the proportion absorbed increasing the lower the dietary concentration of the vitamin. Massive oral dosage (Rose, 1976) is not an effective way of preventing dietary deficiency of vitamin $B_{12}$. A regular dietary intake of the vitamin is required or alternatively periodic massive dose by parenteral injection. The former can easily be achieved by the daily use of foods supplemented with the vitamin (Ellis \& Wokes, 1967). Miller \& Mumford (1972) calculated that a typical daily serving of some vegetable foods that are supplemented with the vitamin would provide $2-6 \mu \mathrm{g}$ of the vitamin, thus meeting requirements.

The health of caucasian vegans appears to differ little from that of omnivores (Hardinge \& Stare, 1954a; Ellis \& Montegriffo, 1970; Ellis, West \& Sanders, 1976; Sanders, 1977). Pregnancy in caucasian vegans and the health of children reared on vegan diets appear to be essentially normal (Thomas, Ellis \& Diggory, 1977; Mumford \& Ellis, unpublished observations; Sanders, 1977). Caucasian vegans tend to have lower concentrations of serum cholesterol and triglycerides and less body fat than omnivores (Hardinge \& Stare, $1954 b$; Sanders, 1977) which suggest that they may be less prone to ischaemic heart disease than omnivores, and according to Aries, Crowther, Drasar, Hill \& Ellis, (1971), caucasian vegans are probably less susceptible to cancer of the colon than omnivores. The vegan diet appears to be adequate provided it comprises a mixture of unrefined cereals, pulses, nuts, fruits and vegetables and is supplemented with vitamins $B_{12}$ and $D$; such a diet will renerally promote normal blood formation.

We are grateful to the South West Thames Regional Health Authority for a grant. This work incorporates results from a thesis for which T. A. B. Sanders was awarded the degree of Doctor of Philosophy in the University of London.

\section{REFERENCES}

Aries, V. C., Crowther, J. S., Drasar, B. S., Hill, M. J. \& Ellis, F. R. (1971). J. Path. 103, 54.

Armstrong, B. K., Davis, R. E., Nicol, D. J., Van Merwyk, A. J. \& Larword, C. J. (1974). Am. J. clin. Nutr. 27, 712 .

Badenoch, A. C. (1952). Br. med. J. 2, 668.

Britt, R. P., Harper, C. \& Spray, G. H. (1971). Q.J. Med. New series. L, 160, 499.

Campbell, R. C. (1967). Statistics for Biologists. Cambridge: Cambridge University Press.

Chanarin, I. (1969). The Megaloblastic Anaemias. Oxford and Edinburgh: Blackwell Scientific Publications.

Cotes, J. E., Dabbs, J. M., Hall, A. M., McDonald, A., Miller, D. S., Mumford, P. \& Saunders, M. J. (I970). J. Physiol., Lond. 209, 30.

Ellis, F. R. \& Montegriffo, V. M. E. (1970). Am. J. clin. Nutr. 23 (3), 249.

Ellis, F. R., West, E. D. \& Sanders, T. A. B. (1976). Plant Foods for Man 2, 43.

Ellis, F. R. \& Wokes, F. (1967). Nutritio Dieta 9, 81.

Hardinge, M. G., Crooks, H. \& Stare, F. J. (1962). Am. J. clin. Nutr. ro, 516.

Hardinge, M. G. \& Stare, F. J. (1954a). J. clin. Nutr. 2, 73.

Hardinge, M. G. \& Stare, F. J. (1954b). J. clin. Nutr. 2, 83.

Heyssel, R. M., Bozian, R. C., Darby, W. J. \& Bell, M. C. (1966). Am. J. clin. Nutr. I8, 176.

Hines, J. D. (1966). Am. J. clin. Nutr. 19, 260.

Ledbetter, R. B. \& Del Pozo, E. (1969). Acta haemat. 42, 247.

Lester Smith, E. (1965). Vitamin $\mathbf{B}_{12}$. London: Methuen \& Co. Ltd.

Miller, D. S. \& Mumford, P. (1972). Pl. Fds hum. Nutr. 2, 201.

Misra, H. N. \& Fallowfield, J. M. (197I). Postgrad. med. J. 47, 624. 
Nutrition Reviews (1975). Nutr. Rev. 33 (4), I 8.

Pallis, C. M. \& Lewis, P. D. (1974). The Neurology of Gastro-intestinal Disease. London: W. B. Saunders Co. Ltd.

Roberts, P. D., James, H., Petrie, A., Morgan, J. O., Hoffbrand, A. V. (1973). Br. med. J. 3, 67.

Rose, M. (1976). Lancet ii, 68I.

Sanders, T. A. B. (1977). The composition of red cell lipid and adipose tissue in vegans, vegetarians and omnivores. Ph.D. thesis: University of London.

Smith, A. D. M. (1962). Br. med. J. I, 1655.

Spray, G. H. (1955). Clin. Sci. 14, 66I.

Stewart, J. S., Roberts, P. D. \& Hoffbrand, A. V. (1970). Lancet ii, 542.

Thomas, J., Ellis, F. R. \& Diggory, P. L. C. (1977). Proc. Nutr, Soc. 36, 46A.

Verjaal, A. \& Timmermans-Van Den Bos, A. H. (1967). J. Neurol. Neurosurg. Psychiat. 30, 464.

West, E. D. \& Ellis, F. R. (1966). J. Neurol. Neurosurg. Psychiat. 29, 39 I.

WHO (1968). Tech. Rep. Ser. Wld Hlth Org. no. 405.

Winawer, S. J., Strieff, R. R. \& Zamcheck, N. (1967). Gastroenterology 53, 130.

Wokes, F., Badenoch, J. \& Sinclair, H. M. (1955). Am. J. clin. Nutr. 3, 375. 